УДК: 75.052

ББК: 85.14

A43

DOI:10.18688/aa166-2-18

Jenny Albani

\title{
The Painted Decoration of the Church of the Virgin at Sklavopoula, Crete
}

Sklavopoula is a little village $20 \mathrm{~km}$ away from the town of Paleochora in the mountainous Province of Selino of the southwestern part of Crete. There is evidence that copper and iron were mined in the settlement in Roman times and, according to Dimitris Tsougarakis, the site was also occupied in the first Byzantine period of Crete $\left(4^{\text {th }}-9^{\text {th }}\right.$ c. $)[34$, pp. 272, 342]. An inscription in the Church of St. George at Sklavopoula, dating its earlier layer of paintings to $1290 / 1291$ [14, pp. 431, 432, no. 1. 5, pp. 71-72. 12, p. 211], provides the evidence that the village existed also in the Venetian period (1210/1211-1669). There are two more religious monuments, datable to the Venetian period, preserved in the village: the Churches of the Virgin ${ }^{1}$ and of the Savior [12, pp. 213-214. 5, pp. 210-211]. Moreover, Sklavopoula was mentioned in a report of the year 1630 by the Italian engineer and cartographer Francesco Basilicata (Venice, Biblioteca Marciana, Mss. Ital. Cl. VI, No. 1683) [27, p. 136].

The Church of the Virgin (Ill. 38) is a single-nave church, measuring $7.66 \times 5.33 \mathrm{~m}$, with a semi-circular apse projecting on the east and pierced by a twin-arched window. The church is covered by a pointed barrel-vault and divided in the interior by a transverse strainer arch in two bays. The floor level of the sanctuary is one step higher than that of the nave. This step is formed by reused marble pieces. The altar is of masonry and there is also a stone bench to the left and a similar one to the right. A rectangular conch is opened in the north wall of the sanctuary. A modern wooden templon screen separates the sanctuary from the nave.

The entrance door is set in the west wall and flanked by a stone frame, over which we see a stone relief panel inserted at a later period. It shows a foliate cross and the year 1893, probably the year of a repair of this wall. Stone benches are built outside the church on either side of the door and inside the building, along the north wall of the nave. The south wall, supported by two buttresses, is pierced by a window, widened at later period. The exterior surfaces of the walls are plastered. The church is built on an earthy platform, on which six tombs dated to the $19^{\text {th }}$ and $20^{\text {th }}$ centuries are arranged.

I would like to thank the Ephorate of Antiquities of Chania for the permission to publish a study on this monument. I am particularly indebted to my colleagues Voula Sarikaki, who shared with me her valuable remarks on the monuments at Sklavopoula, helped me in measuring the church of the Virgin and provided me with photographs of the monument, and Dr. Dimitris Doumas for editing the English text. For short mentions of the monument's wall-paintings, see: [12, pp. 214-215; 5, p. 202; 8, p. 398; 15, p. 31, no 87; 19, pp. $27,33-34,47,51$, fig. 22]. 
The Church of the Virgin is decorated with wall paintings of outstanding quality preserved nowadays in a poor condition. A portrait of a donor with two fragmentarily preserved dedicatory inscriptions (Ill. 41) is placed on the westernmost part of the north wall. The donor [13, p. 330, no 8] is shown as a robust young man with brown hair and short beard. He is depicted in frontal stance with his right hand in prayer and the model of the church in his left. He wears a long dark cloak with sleeves and a short green tunic with a girdle to which a sword decorated with pearls is attached ${ }^{2}$.

According to Giuseppe Gerola [14, p. 433, no 4], the dedicatory inscription to the left of the donor reads: $[\triangle E H] C I[C \ldots]] /$ TOY $\triangle$ OY $\Lambda$ OY TOY $\Theta(\varepsilon o) Y / I \Omega(\alpha \dot{\alpha} v v o v)$ TOY $\Pi O P / T A P I$. To the right of the donor there is the inscription: [ $\triangle E H C I C]$ TOY $\triangle O Y \Lambda O Y$ TOY $\Theta(\varepsilon o) Y / A \Lambda E \Xi I O Y$

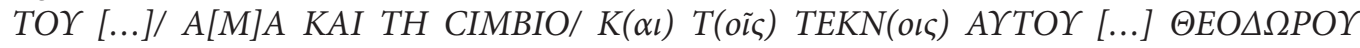
AMHN.

We may thus assume that the erection of the church and its painted decoration were a collective donation by John, Alexius, his wife and his children, as well as Theodore. John $\pi o \rho \tau \dot{\alpha} \rho \iota \varsigma$, portrayed with a richly decorated sword, was probably a high-ranking officer responsible for guarding the gate of a castle or a fortress ${ }^{3}$. After the Revolution of Chortatzis (1272-1278) the Duke of Crete Marino Gradonico erected, in the late $13^{\text {th }}$ century, the Selino Fort (Castel Selino) on the Fortezza hill to the south of modern Paleochora. According to Basilicata, Sklavopoula was under the control of this fortress [27, p. 136], which was severely damaged during the Cretan War (1645-1669)4. The donor of the Church of the Virgin at Sklavopoula may have been associated with this fort.

In the conch of the sanctuary there is the bust of the Virgin Blachernitissa flanked by two tiny adoring angels (Ill. 39). The Christ Child on her lap blesses with both hands. A white strip

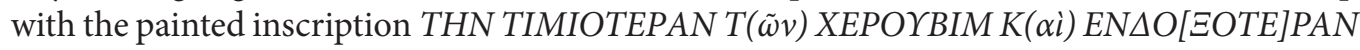

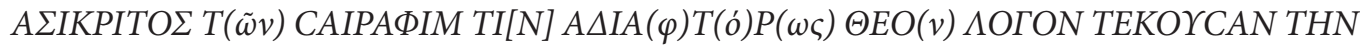

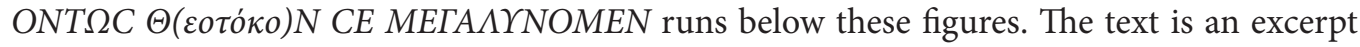
from a hymn composed in honor of the Virgin by Cosmas the Hymnographer, which is chanted in numerous Mariological and Christological feasts.

There are four full-length co-officiating bishops flanking the Melismos painted on the semi-cylindrical part of the apse. They are, from left to right, St. Athanasius of Alexandria $(O$

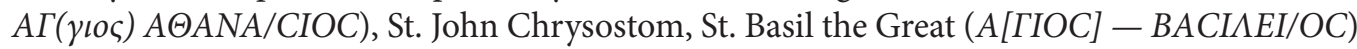
and probably St. Gregory of Nazianzus. The Melismos shows the nude, live figure of Christ Child with a red halo. Eucharistic Christ lies on a paten under the asteriskos and blesses. This image, popular in the $14^{\text {th }}$ and $15^{\text {th }}$ centuries, illustrates a certain phase of the Holy Liturgy -

2 The donors portrayed in the churches of Archangel Michael at Mesa Lakonia (1431/1432), in the Mirambelo Province, and St. George at Kato Floria (1497), in the Selino Province, wear similar clothes. The only difference is that their cloak is sleeveless and that they have no sword. Moreover, they wear a headdress [22, p. 186; 13 , p. 338 , no 48 and p. 333 , no 21 , pls. $16 / 3,10 / 1 ; 15$, p. 37 , no. 138]. The donor of the wall paintings in the church of St. George at Amariano, in the Pediada Province, is clad in a white short tunic with a girdle but has no sword [13, p. 338, no 47, pl. 15/1; 15, p. 80, no. 522].

The word $\pi$ ó $\tau \tau$ - porta was used for a fort's gate [23, pp. 242-247]. Guarding a fort's gate was an office of great importance during the Venetian occupation of Crete [26, pp. 80-81].

4 The fortress appears in a drawing (1609-1638) by Francesco Basilicata [27, pl. 51]. Its ruins have been recently excavated $[3$, p. 338$]$. 
from the beginning of the Anaphora up to the chanting of the Epinikios Hymn - during which the holy bread and wine on the altar are covered only by the asteriskos [17, pp. 94, 246]. To the paten's left is the lance and to the right the sponge and the chalice partially covered by the aer ${ }^{5}$.

The pediment above the conch is decorated with Christ Anapeson ${ }^{6}$ flanked by two angels, an allusion to the Incarnation, Passion and Resurrection of Christ [33, pp. 134-165; 21, pp. 181-196; 4, pp. 287-290], and the Annunciation. Below the Virgin and Archangel Gabriel there are two half-length bishops also flanking the conch. And on the bottom registers of the east wall, on either side of the apse, we can see two holy deacons: St. Stephen $(O A[\Gamma I O C]-$ CTEФAN[OC]), holding a candle in his right hand ${ }^{7}$ and a pyxis in the left, and St. Romanus the Melodist ([O AГIOC] POMANOC/ [M]E $\Lambda[\Omega \triangle O C]$ ).

The barrel vault of the sanctuary is occupied by the Ascension. The Presentation of the Virgin in the Temple is depicted on the south wall. This scene is included in the iconographic programme of the sanctuary in numerous late Byzantine churches due to the Eucharistic symbolism of the Virgin's nourishment by an angel in the Holy of the Holies [20, p. 170]. The bottom register of this wall represents a co-officiating bishop, probably St. Cyril of Alexandria, identifiable by means of his headdress decorated with crosses. On the north wall, below the Ascension, the Sacrifice of Abraham ( $H \Theta H-C I \ddot{A} A T(o \tilde{v}) A[B P A A M])$, a scene with Eucharistic connotation, and the Empty Sepulcher are depicted ${ }^{8}$. Under the conch of this wall a halflength bishop is portrayed in frontal stance.

The barrel vault of the nave is divided in four zones. The upper zone of its south half, to the east of the strainer arch, displays the Pentecost (H ПEN[THKOC]TH) and below this scene the Prayer of St. Anna ([H ПPO]CEY[XH] - THC A[NNHC]) is depicted. To the west of the strainer arch the Nativity $(H X(\rho \iota \sigma \tau o) \Upsilon \Gamma[E N N H C I C])$ and the Crucifixion $H C T A-B P O /$ CIC) are placed on the upper zone of the barrel vault. In the Crucifixion the faces of the personified sun and moon are depicted in medallions on either side of Christ, denoting his sovereignty over the oecumene'.

The lower zone displays the Birth of the Virgin (H IENHCIC TIC $\Theta(\varepsilon o \tau$ (o)KOY) and six figures from the Apostle Tribunal belonging to the composition of the Last Judgment. The

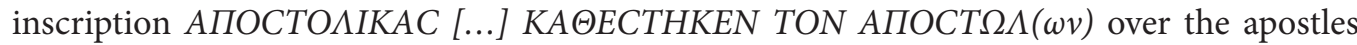
continues on the north wall. The apostles sit on a bench looking towards Christ the Judge and

An exact parallel is the Melismos in the Church of the Virgin at Meronas, in the Amari Province [31, p. 166, fig. 355].

6 A representation of the Anapeson at the same spot appears in the painted decorations of several churches in Venetian Crete [29, p. 146. 32, pp. 136-137, fig. 315].

This rare iconographic detail appears also in the portraits of St. Stephen in the churches of Archangel Michael at Kardaki, in the Amari Province, and St. George at Artos (1401), in the Rethymnon Province [31, p. 105, fig. 313. 11, pp. 86, 88-89].

8 These two scenes are represented at the same spot in the church of St. George at Melissourgaki, in the Mylopotamos Province [25, p. 462].

9 This detail is also encountered in the corresponding scene in the churches of St. Marina at Chalepa, St. George at Margarites, in the Mylopotamos Province, and the Virgin at Meronas [30, pp. 130, 209, figs. 154155, 316. 7, fig. 6]. 
hold open inscribed books ${ }^{10}$. Peter $(\Pi)^{11}$ is at the head of the six (Ill. 40), to the right, followed by John $(I \Omega)^{12}$, Luke $(\Lambda)^{13}$, Andrew $(\mathrm{AN})^{14}$, James $(I B)^{15}$ and probably Thomas.

On the south wall, from east to west, there are the full-length figures of a monk, St. Nicholas

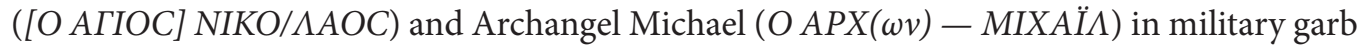
(Ill. 42). The archangel raises his sword with his right hand while he holds an open inscribed

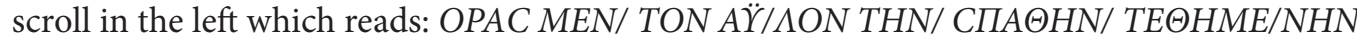
$\Pi P O / T O(v) \Pi I \Lambda O N$. He is thus shown as guardian of the church [16, pp. 284-285], of Paradise, which is depicted on his right, and perhaps, also of the Castel Selino, in association with the donor John portrayed almost opposite him. The Paradise is shown as a walled garden, inside which the Virgin $(M(\dot{\eta} \tau \eta) P \Theta(\varepsilon o) Y)$ and Patriarch Abraham, who holds two tiny souls, are sitting on a bench. Between them there is a cherubim, while the Good Thief is sitting on a bench above the Paradise's fortified gate which is decorated with pearls.

On the tympanum of the west wall, there is the Deisis preserved in a poor condition. Under this composition, to the left, there is a choir of Righteous partially preserved. On the west wall, to the left of the door, we see the Personifications of the Earth and the Sea releasing the dead, depicted in two registers. The Earth is depicted as a young woman in royal attire. The Sea $(H$ $\Theta A \Lambda A C A \triangle I \Delta[O Y C A] /$ THC EAYTHC NEKP[OYC]) is shown as a nude woman with a crown of crabs, riding a huge fish ${ }^{16}$.

To the right of the door there is a representation of the Hell articulated in three horizontal registers. On the upper panel Hades is depicted as an old nude man riding a monster in a fiery landscape. On the two lower friezes the Damned in $\mathrm{Hell}^{17}$ are represented nude against

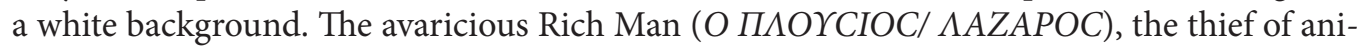

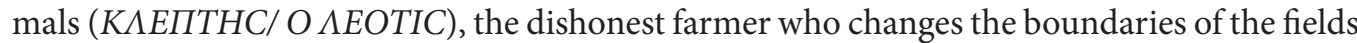
and ploughs another man's land $(O \Pi A[P] A / B \Lambda A K I C T H C)$, the fornicator $(O \Pi O P N O C)$,

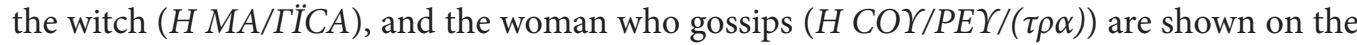
upper frieze. The couple who sleep on Sunday instead of going to church (OI [K]OIMONTEC THN KYPIAKHN), the murderer (O $\Phi O N(\varepsilon \dot{v} \varsigma))$, the woman who does not offer the loaf of holy bread to the church (OПOY $\triangle E N ~ П Р О С Ф Е Р Е I \Pi P O C / Ф O P A C T H E K \Lambda I C(i \alpha)$ ), the usurer (O ZOYPAPIC), and the miller $(O M I \Lambda O N(\grave{\alpha} \varsigma))$ are depicted below.

The upper zone of the north half of the barrel vault, to the west of the transverse arch, is

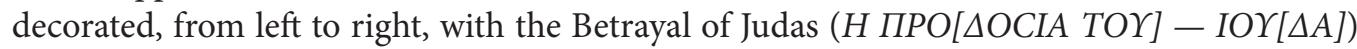
and the Presentation of Christ in the Temple ([H Y]ПAПANTH). In this scene, Symeon, hold-

10 A similar iconography of the Apostle Tribunal, which is, however, depicted on the west wall, under the Deisis, appears in the churches of St. John the Evangelist at Asfendiles, in the Selino Province, St. John the Evangelist at Kissos, in the Agios Basileios Province, and St. George at Artos [18, fig. 3A. 24, p. 138, fig. 19. 32, p. 99, fig. 205. 11, pp. 145-151].

11 Inscription in the book: ПЕIPAC/ KA

12 Inscription in the book: $M H$ А/ГАП/ATE - TA [EГ]KOC/MIA.

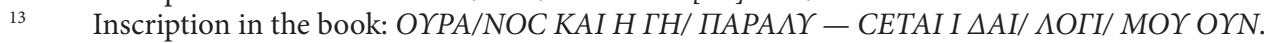

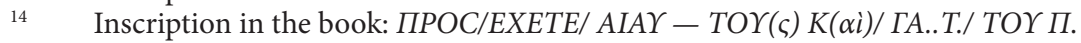

15 Inscription in the book: $\Theta I A . /[\ldots] \Delta[\ldots] / T E .-H M E / P A C / O Y \Delta$.

16 Cf. the Personification of the Sea in the church of St. John the Evangelist at Kissos [32, p. 104, fig. 214].

17 With the exception of the woman who gossips, all the damned in the church of the Virgin at Sklavopoula are encountered in the depiction of the Hell in the Church of St. John the Baptist at Axos, in the Mylopotamos Province [2, pp. 180-184]. 
ing Christ Child, stands to the right of a ciborium. Prophetess Anna is depicted behind him

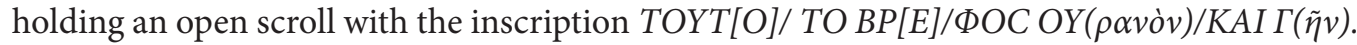
The two registers below these scenes, looking from west to east, display six apostles of the Last

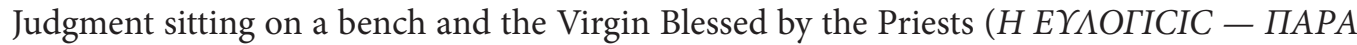
$T(\alpha \tilde{\zeta})$ IEPAIC). Over the apostles runs the inscription KPINONTAC ФH [AC...] АПACAC $H C(\rho \alpha \dot{\eta}) \Lambda A I \Delta H T$. The apostles are (from left to right): Paul $(\Pi A)^{18}$, Matthew $(M A \Theta)^{19}$, Marc $(M A)^{20}$, Bartholomew $(B)^{21}$, Simon $(C I)^{22}$, and Philip $(\Phi)^{23}$.

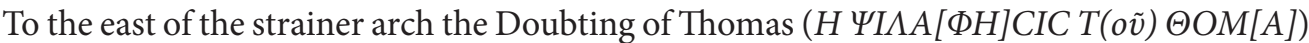
(Ill. 43) is painted on the upper part of the barrel vault and the Anastasis $(H X(\rho l \sigma \tau o) Y$ $A N A[C T A C I C]$ ) on the lower. The north wall of the nave, from west to east, is decorated with the donor portrait, the figures of the military saints Demetrius ( $O A \Gamma(\llcorner\circ) \triangle H M I T P I / O C)$, Theodore $(O A \Gamma(\iota 0) C \Theta E O \triangle \Omega P O C)$ and George on horseback (Ill. 44), as well as a representation of the Virgin Hodegetria enthroned.

On the apex of the transverse arch, the Holy Mandylion ending in two knots ${ }^{24}$, with the inscription $I(\eta \sigma o \tilde{v}) C[X(\rho\llcorner\sigma \tau o ́) C]$, is flanked by four full-length figures of prophets. They are very badly preserved except for David (Ill. 45) and Solomon. David holds an open scroll with the inscription $A N E B / H O \Theta(\varepsilon \dot{o}) C / E N A \Lambda / \Lambda A \Gamma M / O K(v \dot{\rho} \iota 0) C$ which is an excerpt from the $46^{\text {th }}$ psalm.

The iconographic program of the Church of the Virgin includes seven scenes from the Dodekaorton. The Christological cycle was enriched with one episode from the Passion cycle and two scenes from the Eothina cycle, which emphasize the idea of salvation, further accentuated by the depiction of Christ Anapeson and related to the donors' prayers. The restricted Mariological cycle, which consists of four scenes, and the portrait of the Hodegetria included in the program for the church are dedicated to the Virgin, who is, moreover, the most important intercessor for the salvation of mankind. The eschatological character of the program is further accentuated by the large composition of the Last Judgment in the western part of the church in association with St. Nicholas, an intercessor par excellence, and Archangel Michael, the psychopompos and the guardian of Paradise's gate. Female saints were omitted from the iconographic program in question. On the other hand, an emphasis was given to the portraits of Sts. Demetrius, Theodore and George, which may betray a particular devotion of the donor John, being a military officer, to "military" saints.

The wall paintings in the Church of the Virgin at Sklavopoula may be attributed to the work of two first class artists and of at least one assistant. The first painter, rather a "portrait master", was probably responsible for the hagiographic portraits of the nave and the figures in the semi-dome of the sanctuary. These figures, with best preserved examples the Virgin

\footnotetext{
18 Inscription in the book: $B \Lambda(\dot{\varepsilon}) / \Pi E T E A / \triangle E \Lambda-\Phi I M / O Y$ AKPI/BOC.

19 Inscription in the book: O MI/ ГАP E $/ \Theta H$ - OY I ГE/NEA/ AYTI.

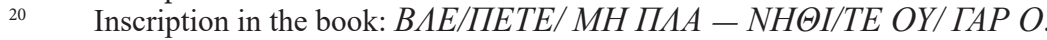

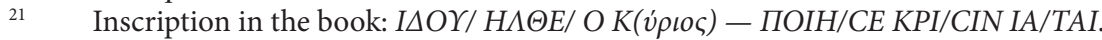

22 Inscription in the book: OPА/TE А/ГАПН/TOI - H/АCIC A/ПОГI/NO C.

23 Inscription in the book: ACФA/ IEICA/CTE EAY - TOYC/ TIC SPAC EKI/NHC.

24 Cf. the depiction of the Mandylion in the churches of St. Nicholas outside Meronas, Archangel Michael at Kardaki, St. George at Cheliana (1319), in the Mylopotamos Province, and St. Paraskevi at Arkadi, in the Rethymnon Province [31, pp. 283-284, figs. 431, 301; 30, fig. 175; 28, p. 348, fig. 79].
} 
Blachernitissa (Ill. 40), Archangel Michael (Ill. 42) and the "military" saints (Ill. 44), emit strong monumentality and reveal a deep indebtedness to classical models. Moreover, they are characterized by an introspective mood. Their faces are thin and elongated, with subtle modeling and fine, carefully drawn physiognomic traits. Their distant and melancholic glance is accentuated by the oval thick eyebrows and the brown shading on the eyelid and below the eye. In addition, white brushstrokes highlight the corner of the eyes, the nose and the forehead. Figures by this painter find close stylistic parallels in the frescoes of the west cupola in the Church of the Holy Apostles at Leondari, in the Peloponnese, related to the art of the capital and dated on stylistic grounds to between 1370 and $1390^{25}$.

The second artist was probably responsible for the scenic representations, the co-officiating bishops and the figures of the transverse arch. He was also an accomplished painter characterized by a somewhat expressionistic handling of the brushwork. Figures by this master indicate an awareness of the outer world. Their faces are fleshier, with a rather harsh modeling, and their sharp glance is accentuated by linear, oblique eyebrows and brown shading on the eyelids. The drapery is rendered in numerous folds with their contours in a dark tone of the local color and large highlighted areas in white.

The scenes of the Christological cycle are rather crowded compositions with an architectural backdrop of a rather simple character (Ill. 43). The human figures and the architecture coexist in a harmonious dialogue which conveys a feeling of space, while red draperies are floating between the buildings creating decorative effects. The gamut of colors is rich, vivid red, ochre, emerald green, gray blue being the dominant colors.

The refined style of the wall paintings in the Church of the Virgin at Sklavopoula can be associated with a stylistic trend of late Byzantine painting. This trend, revealing a classicist taste of undoubtedly Constantinopolitan origin, is represented in Crete by the painted decoration of about 24 churches assigned to the period between 1380 and 1417 [8; 7, pp. 417, 422-424; 9, pp. 236-237; 24, pp. 147-148]. Although no comparative material from contemporary monumental painting in Constantinople is extant, written sources provide evidence of travelling artists from Constantinople to Crete as well as the patriarch's interest in the Cretan ecclesiastic life [9, pp. 240-241; 6, pp. 113-114]. Constantinopolitan masters could have worked together with Cretan painters and apprentices in Cretan churches of aristocratic patronage.

A key monument for understanding aforementioned artistic developments in Crete is the Church of the Virgin at Meronas, with frescoes similar in style with those in the Church of the Virgin at Sklavopoula ${ }^{26}$. The erection of the church at Meronas and its painted decoration are securely associated with the prominent Cretan family of Kallergis by means of the depiction in relief and fresco of their coat of arms [8, pp. 409-410; 6, p. 105, figs. 1-2; 7, p. 417). The aristocratic donor of this church, probably Matthew Kallergis [6, p. 114], may have engaged one or more Constantinopolitan artists for its decoration. The outcome is a work of exceptional

25 E.g. the figure of Archangel Michael in the church of the Virgin at Sklavopoula (Ill. 42) and the figure of the archangel above the south window of the western cupola in the church of the Holy Apostles at Leondari [1, fig. 10]. For the dating of these frescoes, see [1, p. 171].

${ }_{26}$ The figural types in both churches belong to the same artistic tradition. For example, St. Athanasius of Alexandria and Prophet David (Ill. 45) in the church of the Virgin at Sklavopoula bear many stylistic affinities with the co-officiating bishops in the church of the Virgin at Meronas [31, figs. 358-360]. See also 7, p. 426. 
quality, dated on stylistic grounds between 1380 and 1390 [8, p. 406; 6, p. 112; 5, p. 199]. A metropolitan origin of the artists who painted the frescoes of the Virgin at Sklavopoula, which share iconographic and stylistic resemblances with those at Meronas, may also be suggested. Although the worn dedicatory inscription of the church does not inform us nowadays on the status of Alexius and Theodore, it indicates that the donor John was probably a high-ranking military officer who may have engaged the Meronas workshop for the murals of the church of the Virgin at Sklavopoula.

Moreover, a comparison of the wall paintings of the Church of the Virgin at Sklavopoula with those in the Church of St. Athanasius at Kephali ${ }^{27}$, in the Kissamos Province, dated by inscription to the year 1393, revealed stylistic affinities in the rendering of figures and articulation of compositions indicating that at least one painter, probably the "master of the compositions", participated in both projects. Further resemblances of facial types and the rendering of figures can be observed between the Sklavopoula frescoes and the wall paintings in the Churches of St. John the Baptist at Erfoi ${ }^{28}$ and St. George at Melissourgaki ${ }^{29}$, in the Mylopotamos Province, as well as of the Savior at Agios Ioannis ${ }^{30}$, in the Agios Basileios Province, dated on stylistic grounds to the last decade of the $14^{\text {th }}$ century and around 1400. Compared with the wall paintings in the Church of St. George at Artos from the year 1401, the frescoes of the Church of the Virgin at Sklavopoula also reveal similar compositional approaches ${ }^{31}$. The aforementioned stylistic affinities favor our conclusion that the painted decoration of the Church of the Virgin at Sklavopoula dates to the last decade of the $14^{\text {th }}$ century.

Title. The Painted Decoration of the Church of the Virgin at Sklavopoula, Crete.

Author. Jenny Albani - Ph. D., tutor. Hellenic Open University, Parodos Aristotelous 18, 26335 Patra, Greece). jennyalbani@gmail.com

Abstract. The Church of the Virgin at Sklavopoula in the Selino Province of the southwestern part of Crete is a single-nave church decorated with wall paintings of outstanding quality preserved nowadays in a poor condition. According to the painted dedicatory inscription, John, probably a high-ranking officer responsible for guarding the gate of the fort (presumably, the Castel Selino in the modern Paleochora), Alexius, his wife and his children, and Theodore were the donors of the erection and decoration of the church.

The iconographic program of the wall paintings includes seven scenes from the Dodekaorton. The Christological cycle was enriched with one episode from the Passion cycle and two scenes from the Eothina cycle, which emphasize the idea of salvation. A restricted Mariological cycle, which consists of four scenes, and a portrait of the Virgin Hodegetria was also included in the program since the church is dedicated to the Virgin, who is the most important intercessor for the salvation of mankind. The eschatological character of the

$27 \quad$ E.g. the group of the Apostles in the scene of the Doubting of Thomas at Sklavopoula (Ill. 43) and the group of the Apostles in the scene of the Washing of the Feet at Kephali [29, fig. 130].

${ }_{28}$ E.g. two Apostles of the Pentecost at Sklavopoula and Prophet Kings David and Solomon of the Anastasis at Erfoi [30, fig. 256].

29 The modeling of the face of the angels raising the Glory of Christ in the Ascension at Sklavopoula is comparable to that of the corresponding figure in the church of St. George at Melissourgaki [25, fig. 3]. Comparable are also the scenes of the Empty Sepulcher and the Betrayal at Sklavopoula with the corresponding scenes at Melissourgaki [25, figs. 6, 8].

30 E.g. the figure of St. Gregory of Nazianzus in the church of the Virgin at Sklavopoula and that of St. Athanasius in the church of the Savior at Agios Ioannis [32, fig. 26] as well as the figure of the Virgin inside the Paradise in the church of the Virgin at Sklavopoula and that of the Virgin in the church of the Savior at Agios Ioannis [32, fig. 24].

${ }_{31}$ E.g. the Betrayal of Judas, the Doubting of Thomas, and the Apostle Tribunal [29, fig. 135; 11, pls. I.2, $\mathrm{I} \Delta .1-2]$. 
program is further accentuated by the large composition of the Last Judgment in the west part of the church in association with St. Nicholas, an intercessor par excellence, and Archangel Michael, the psychopompos and guardian of the Paradise's gate.

The wall paintings of the Church of the Virgin at Sklavopoula may be attributed to the work of two first class artists and at least one assistant. On stylistic grounds, they date to the last decade of the $14^{\text {th }}$ century. Their refined style can be associated with a classicist stylistic trend of undoubtedly Constantinopolitan origin, which is represented on Crete by painted decorations of about 24 churches assigned to the period between 1380 and 1417.

Keywords: wall paintings; Venetian period; donor portrait; dedicatory inscription; Dodekaorton; Passion cycle; Eothina cycle; Last Judgment; classicist stylistic trend.

Название статьи. Фрески церкви Богородицы в Склавопуле (о. Крит).

Сведения об авторе. Албани Дженни - Ph. D., преподаватель. Открытый греческий университет, проезд Аристотеля, 18, Патра, Греция, 26335. jennyalbani@gmail.com

Аннотация. Церковь Богородицы в деревне Склавопула (епархия Селино, юго-западный Крит) - небольшая однонефная постройка, украшенная фресками исключительного художественного качества, которые дошли до наших дней в сложном состоянии сохранности. В соответствии с посвятительной надписью, Иоаннис - вероятно, военный высокого ранга, ответственный за охрану ворот форта (по всей видимости, замка Селино в северной Палеохоре), Алексий, его жена и его дети, а также Феодора являлись донаторами, благодаря которым была возведена и оформлена эта церковь.

Программа росписи включает семь сюжетов из Додекаортона. Христологический цикл обогащен сценой из цикла Страстей и двумя сценами из евангельских стихир, в которых подчеркнута идея спасения. Мариологический цикл, пусть и ограниченный, состоящий всего из четырех сцен и изображения Богоматери Одигитрии, также включен в ансамбль, поскольку церковь посвящена Деве Марии - главной заступнице рода человеческого на пути ко спасению. Эсхатологический характер программы сказался также в особом значении, приданном св. Николаю, предстательствующему за людей, и архангелу Михаилу, психопомпу и стражу райских дверей, в большой композиции «Страшного суда» в западной части церкви.

В создании росписей в церкви Богородицы в Склавопуле, очевидно, участвовали два первоклассных мастера и по меньшей мере один подмастерье. Они могут быть датированы на основании стилистики последним десятилетием XIV в. Их изысканный стиль связан с классицизирующей тенденцией несомненно константинопольского происхождения, которая представлена на Крите росписями двадцати четырех церквей, относящихся к периоду между 1380 и 1417 гг.

Ключевые слова: фрески; венецианский период; портрет донатора; посвятительная надпись; Додекаортон; страстной цикл; евангельские стихиры; Страшный суд; классицизирующая стилстическая тенденция.

\section{References}

1. Albani J. The Painted Decoration of the Cupola of the Western Gallery in the Church of the Holy Apostles at Leondari. Cahiers Archéologiques, 1992, vol. 40, pp. 161-180.

2. Albani J. The Wall Paintings of the Church of Saint John at Axos of Mylopotamos. O Mylopotamos apo ten Archaiotete os Semera. Periballon - Archaiologia - Istoria - Laographia - Koinoniologia. V. Byzantinoi Chronoi. Praktika Diethnous Synedriou (Mylopotamos from the Antiquity to the Present Day. Environment - Archaeology - History - Folklore - Sociology. V. Byzantine Times. Acts of International Congress). Rethymnon, Historike kai Laographike Hetaireia Rethymnou Publ., 2006, pp. 159-196 (in Greek).

3. Andrianakis M. 28 $8^{\text {th }}$ Ephorate of Byzantine Antiquities. 2000-2010. Apo to anaskaphiko ergo ton ephoreion archaioteton (2000-2010. From the Excavation Work of the Ephorates of Antiquities). Athens, Ypourgeio Paideias kai Threskeumaton, Politismou kai Athletismou Publ., 2012, pp. 335-340 (in Greek).

4. Belting H. Likeness and Presence. A History of the Image before the Era of Art. Chicago - London, The University of Chicago Press Publ., 1994. 651 p.

5. Bissinger M. Kreta. Byzantinische Wandmalerei [Münchener Arbeiten zur Kunstgeschichte und Archäologie, 4]. Munich, Editio Maris Publ., 1995. 278 p. (in German).

6. Borboudaki M. The Church of the Virgin of Meronas and the Kallergis Family. Cahiers Archéologiques, 2013-2014, vol. 55, pp. 104-118. 
7. Borboudaki M. The Painted Decoration of the Church of the Virgin at the Village Meronas of Amari: New Elements. Aphieroma ston akademaiko Panagiote L. Bokotopoulo (Dedication to Academician Panagiotis L. Vocotopoulos). Athens, Ekdoseis Kapon Publ., 2015, pp. 417-427 (in Greek).

8. Borboudakis M. The Wall Paintings of the Panagia of Meronas and a Specific Trend of the Cretan Painting. Pepragmena tou $E^{\prime}$ Diethnous Kretologikou Synedriou (Acts of the $5^{\text {th }}$ International Cretological Congress), vol. 2. Herakleion, Hetaireia Kretikon Historikon Meleton Publ., 1985, pp. 390-412 (in Greek).

9. Borboudakis M. The Art during the Venetian Occupation. Krete: Istoria kai Politismos (Crete: History and Civilization), vol. 2. Crete, Syndesmos Topikon Enoseon kai Demon Publ., 1988, pp. 233-288 (in Greek).

10. Darvaris D. N. Grammatike aploellenike (Grammar of Simple Greek). Vienna, Hellenike typographia Georgiou Bendiote Publ., 1806. 424 p (in Greek).

11. Drandakis N. B. The Small Church of Saint George in Artos of Rethymne. Kretika Chronika (Cretan Annals), 1957, vol. 11, pp. 65-161 (in Greek).

12. Gallas K.; Wessel K.; Borboudakis M. Byzantinisches Kreta. Munich, Hirmer Verlag München Publ., 1983. 502 p. (in German).

13. Gerola G. Monumenti Veneti nell' isola di Creta, vol. 2. Venice, R. Istituto Veneto di Scienze, Lettere ed Arti Publ., 1908. 391 p. (in Italian).

14. Gerola G. Monumenti Veneti nell' isola di Creta, vol. 4. Venice, R. Istituto Veneto di Scienze, Lettere ed Arti Publ., 1932-40. 626 p. (in Italian).

15. Gerola G.; Lassiothakis K. E. Topographikos katalogos ton toichographemenon ekklesion tes Kretes (Topographical List of Churches with Frescoes in Crete). Herakleion, Hetaireia Kretikon Historikon Meleton Publ., 1961. 158 p. (in Greek).

16. Georgitsoyanni E. N. Les peintures murales du Vieux Catholicon du Monastère de la Transfiguration aux Météores (1483) ["Bibliothèque Sophie N. Saripolos", 92]. Athens, Université nationale et capodistriaque d’Athènes. Faculté de philosophie Publ., 1993. 635 p. (in French).

17. Konstantinidi Ch. O Melismos. Oi sylleitourgountes hierarches kai oi aggeloi-diakonoi mprosta sten hagia trapeza me ta timia dora e ton eucharistiako Chresto (The Melismos. The Co-officiating Hierarchs and the Angel-Deacons Flanking the Altar with the Holy Bread and Wine or the Eucharistic Christ) [Byzantine Monuments, 14]. Thessaloniki, Kentro Byzantinon Ereunon Publ., 2008. 486 p. (in Greek).

18. Maderakis S. N. The Hell and the Punishments of the Damned as Subjects of the Last Judgment in Churches of Crete. 1. Introduction: The Subjects of the Last Judgment in Crete (Historical Development). Ydor ek Petras (Water from Stone), July - December 1978, vol. 1/no. 2, pp. 185-286 (in Greek).

19. Maderakis S. N. The Hell and the Punishments of the Damned as Subjects of the Last Judgment in Churches of Crete. 3. The punishments. Ydor ek Petras (Water from Stone), January - December 1979, vol. 2/no. 3-4, pp. 21-80 (in Greek).

20. Mantas A. G. To eikonographiko programma tou ierou bematos ton mesobyzantinon naon tes Elladas (843-1204) (The Iconographic Program of the Holy Bema of the Middle Byzantine Churches in Greece [843-1204]) [Bibliotheke Sofias N. Saripolou, 95]. Athens, Ethniko kai Kapodistriako Panepistemio Athenon. Philosophike Schole Publ., 2001. 359 p. (in Greek).

21. Pallas D. I. Die Passion und Bestattung Christi in Byzanz. Der Ritus - das Bild [Miscellanea Byzantina Monacensia, 2]. Munich, Institut für Byzantinistik und neugriechische Philologie der Universität München Publ., 1965. 339 p. (in German).

22. Panagiotakis G. I. Krete. Istoria - Eikones (Crete. History - Images), vol. 1. Irakleio, G. Panagiotakis Publ., 1990. 399 p. (in Greek).

23. Platon N. Contribution to the Toponyms, Topography and History of the Cities and Fortresses of Crete. A'. The Wall of Chandax during the Second Byzantine Period. Kretika Chronika (Cretan Annals), 1947, vol. 1, pp. 239-255 (in Greek).

24. Pyrrou N. The Wall Paintings of St. John the Theologian in Kissos of Agios Basileios. Praktika tou Diethnous Epistemonikou Synedriou "E Eparchia Agiou Basileiou apo ten archaioteta mechri semera". Periballon - Archaiologia - Historia - Koinonia. Byzantinoi Chronoi - Benetokratia (Acts of the International Scientific Congress "The Province of Agios Basileios from Antiquity to the Present Day". Environment - Archaeology - History - Society”. Byzantine Period - Venetian Occupation), vol. 2. Rethymnon, Omospondia Syllogon Eparchias Agiou Basileiou Rethymnou "O Preveles" - Attikes Syllogos Epistemonon epistemonon Demou Lampes, 2014, pp. 111-152 (in Greek). 
25. Pyrrou N. The Church of Saint George in Melissourgaki, Mylopotamos. Daskala. Apodosi times sten omotime kathegetria Maire Panagiotide-Kesisoglou (Teacher. Tribute to Professor Emerita Mary Panagiotide-Kesisoglou). Athens, Panepistemio Athenon - Saripoleio Idryma Publ., 2014, pp. 455-483 (in Greek).

26. Spanakis S. Regulation of the Guard of the Kingdom of Crete (1588). Kretika Chronika (Cretan Annals), 1948, vol. 2, pp. 73-92 (in Greek).

27. Spanakis S. G. Mnemeia tes Kretikes Istorias. Francesco Basilicata. Relazione 1630 all' Ill.mo ed Ecc.mo S.re, S.re ed Padrone mio Col.mo il S.r Pietro Giustiniano Digniss.mo Cap.no G: nel Regno di Candia (Monuments of the Cretan History). Francesco Basilicata. Relazione 1630 all' Ill.mo ed Ecc.mo S.re, S.re ed Padrone mio Col.mo il S.r Pietro Giustiniano Digniss.mo Cap.no G: nel Regno di Candia), vol. 5. Herakleion, Sphakianos Publ., 1969. 328 p. (in Greek).

28. Spatharakis I. Byzantine Wall Paintings of Crete, vol. I. Rethymnon Province. London, The Pindar Press Publ., 1999. 372 p.

29. Spatharakis I. Dated Byzantine Wall Paintings of Crete. Leiden, Alexandros Press Publ., 2001. 240 p.

30. Spatharakis I. Byzantine Wall Paintings of Crete, vol. 2. Mylopotamos Province. Leiden, Alexandros Press Publ., 2010. 366 p.

31. Spatharakis I; Van Essenberg T. Byzantine Wall Paintings of Crete, vol. 3. Amari Province. Leiden, Alexandros Press Publ., 2012. 325 p.

32. Spatharakis I. Byzantine Wall Paintings of Crete, vol. 4. Agios Basileios Province. Leiden, Alexandros Press Publ., 2015. 262 p.

33. Todić B. Anapeson. Iconographie et signification du thème. Byzantion, 1994, vol. 64, pp. 134-165 (in French).

34. Tsougarakis D. Byzantine Crete. From the $5^{\text {th }}$ Century to the Venetian Conquest [Historical Monographs, 4]. Athens, S. D. Bassilopoulos Historical Publications Publ., 1988. 462 p. 


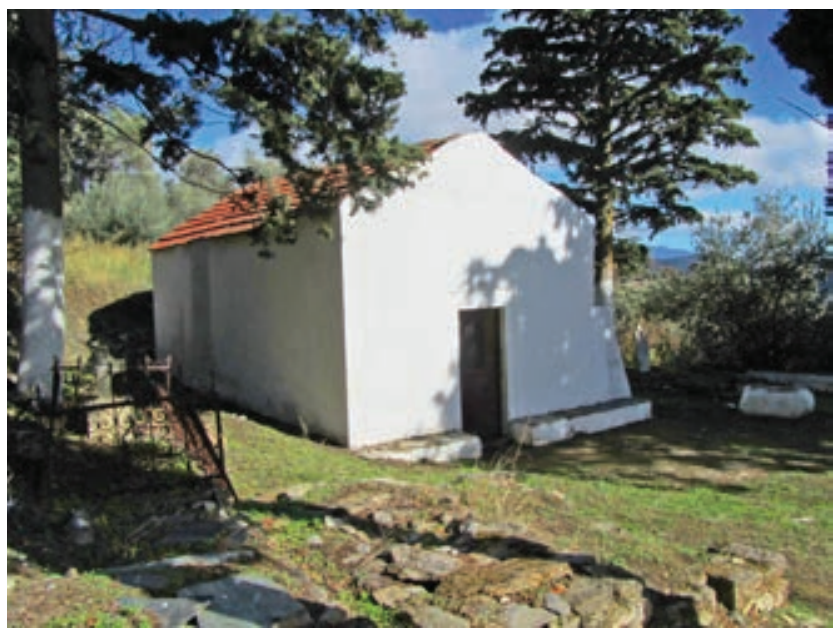

Ill. 38. The church of the Virgin at

Sklavopoula, Crete.

View from North-West

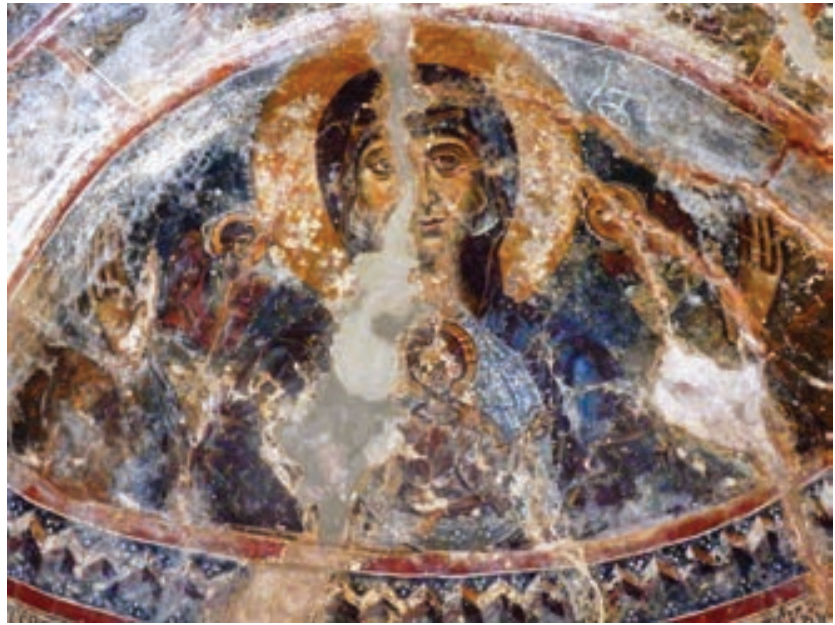

Ill. 39. Virgin Blachernitissa and Child flanked by

adoring Angels. The church of the Virgin at Sklavopoula, Crete

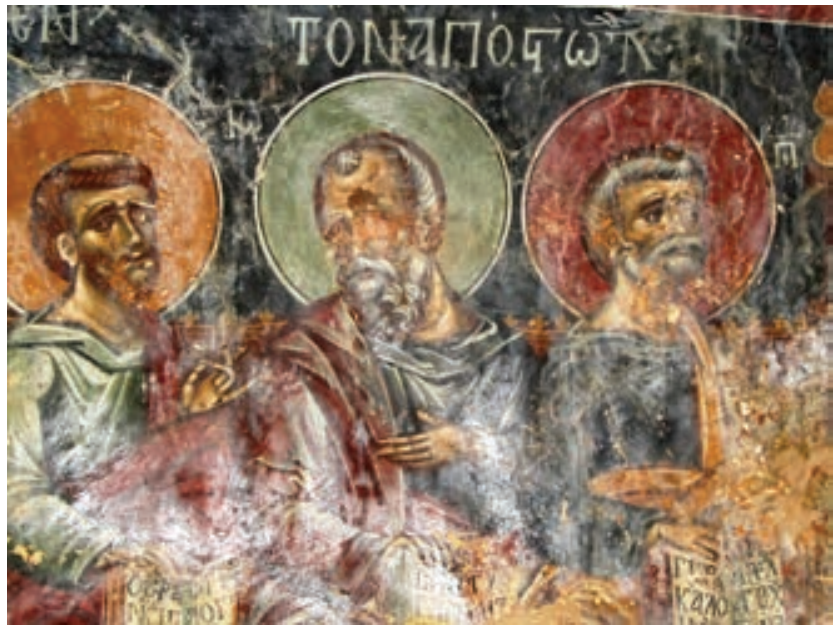

Ill. 40. Apostles Peter, John and Luke. Detail of the Apostolic Tribunal. The church of the Virgin at Sklavopoula, Crete 


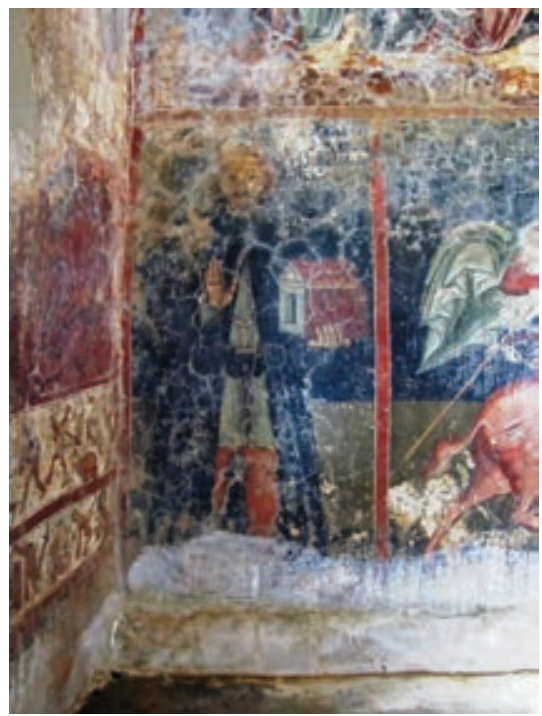

Ill. 41. The donor portrait and the dedicatory inscriptions. The church of the Virgin at Sklavopoula, Crete

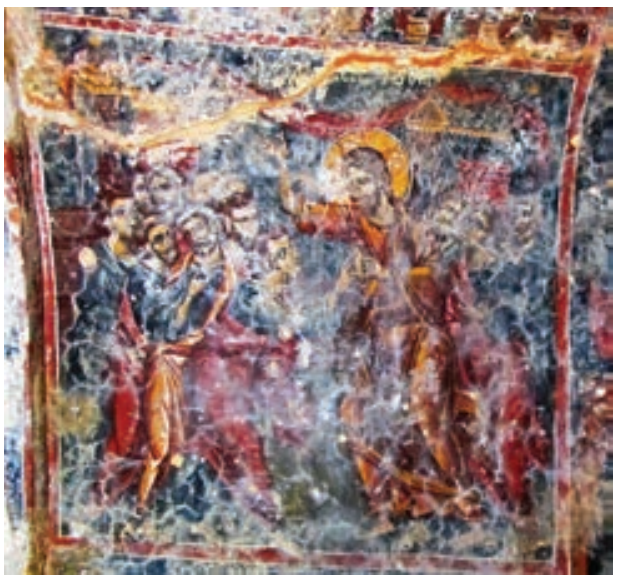

Ill. 43. Doubting of Thomas. The church of the Virgin at Sklavopoula, Crete

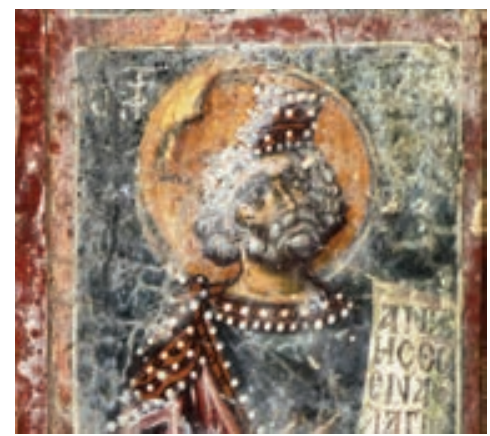

Ill. 45. Prophet David. Detail.

The church of the Virgin at Sklavopoula, Crete
Ill. 42. Archangel Michael. The church of the Virgin at Sklavopoula, Crete

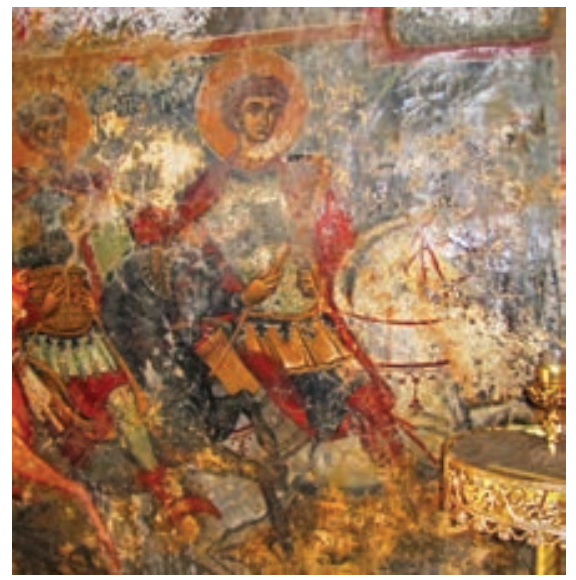

Ill. 44. Saints George and Theodore on horseback. The church of the Virgin at Sklavopoula, Crete 